\title{
The Effect Of Country Of Origin, Brand Image, Price Fairness, And Service Quality On Loyalty Toward IPhone Mobile Users, Mediated By Consumer Satisfaction
}

\author{
Frydom Nainggolan and Anas Hidayat
}

\begin{abstract}
The aim of this research is to determine whether country of origin, brand image, price fairness and service quality affect the satisfaction of iPhone users and to find out whether the satisfaction of iPhone users affect brand loyalty. Novelty in this research was the country of origin because Indonesian consumers were more concerned with the country of origin of the product rather than the quality or other things while others were not concerned about it and it might bring up different things in this research.
\end{abstract}

The populations in this research were iPhone mobile users at the universities in Yogyakarta. The samples in this research were 250 iPhone users. The sampling used non-probability techniques with convenience sampling method and the research models were analyzed using Structural Equation Model (SEM) with the help of AMOS software.

The results of this research proved that country of origin, brand image, price fairness and service quality had significant positive effect on customer satisfaction of iPhone users and iPhone customer satisfaction had significant positive effect on brand loyalty.

Index Terms - Country of Origin, Price Fairness, Service Quality, Customer satisfaction, Customer Loyalty.

\section{INTRODUCTION}

Competitions among producers occur in all industrial sectors. The information technology industry sector is an industrial sector where the level of competition has been high in recent years. Asia in the past few years is a very attractive and lucrative market for information technology producers and surprisingly the biggest growth is in the Southeast Asia region.

As in [2] Growth from Knowledge (GFK), in Southeast Asia Indonesia ranks the highest in the growth of the smartphone market. In the first quarter of 2018 as in [1] eMarketer research institute reported that smartphone active users in Indonesia grew almost twice that of 55 million in 2015 and become 100 million people in 2018.

The impact of the rapid growth of smartphone users has led to increasingly fierce competition in the smartphone industry in recent years and made all smartphone companies try to build and maintain loyalty. In this case, the company does not only require to be able to provide a variety of values or benefits in order to make consumers choose a particular brand of mobile phone, but the company must

Published on February 27, 2020.

Frydom Nainggolan, Universitas Islam Indonesia, Indonesia.

(e-mail: frydom98@gmail.com).

Anas Hidayat, Universitas Islam Indonesia, Indonesia.

(e-mail: 883110102@uii.ac.id) also continue to make various efforts to build customer satisfaction to create loyalty toward their products.

iPhone is one of the many respected smartphone manufacturers today. This American company controls most of the market share in the world. As in [3] Gartner research institute in 2018, the iPhone recorded $14.1 \%$ market share, Samsung $20.5 \%$, Huawei $10.5 \%$, Xiomei $7.5 \%$ and Oppo $7.4 \%$ and in 2019 decreased to third followed by Huawei with the market share 15.8 while the iPhone 10.5 and this must be considered by Apple as the iPhone manufacturer.

Nowadays consumers of mobile phones are generally influenced by many factors in determining the choice of purchasing mobile phones including brand image, price fairness, country of origin, and service quality. Consumers also think whether the features and product characteristics of a brand match what they want and need or they have other considerations when deciding to buy products from a particular brand.

Customer satisfaction is the basis for the success of a company, especially in conditions of intense global competition like today as in [4]. The basis of thinking that underlies the premise of the meaning of customer satisfaction is that consumers who are satisfied with a product / service provided will most likely repurchase and will apply otherwise.

Many empirical researches are conducted to find and analyze factors that can influence the level of customer satisfaction. As in [5], he stated that consumer satisfaction depends on the quality of the product itself. Meanwhile, as in [6]; [7] stated that service quality is the key to customer satisfaction.

Service quality will be an important variable in the company's efforts to obtain long-term relationships with consumers and can attract prospective new customers. For that the company must pay attention to the ease of information about the products they will sell starting from purchasing information, exchange, and spare parts.

In addition to service quality, an important factor in influencing individual consumer satisfaction is price fairness. Based on the customer's point of view, price is very often used as an indicator of value when the price is connected as a perceived benefit of goods / services as in [8]. Price is one way for companies to suppress consumer interest in making purchases.

Brand image is also an important factor in customer satisfaction. Brand image allows consumers / customers to recognize, evaluate the quality of the product to be purchased, and can cause a low purchase risk. Consumers generally prefer well-known brands even though the price 
offered is more expensive as in [9].

As in [10], Country of origin is the country where the company is associated. As in [11] the influence of country of origin on brand image is interesting to be studied because consciously generally country of origin influences the public's view of product quality.

Smartphone manufacturers today can easily copy all aspects of their competitors such as product quality, price fairness and quality of service. However, the existence of a country of origin label that cannot be copied by other producers will create a strength point in terms of product marketing because it will create a strong brand image.

As in [30], Asian consumers especially Indonesia have a culture that is more concerned with the country of origin of a product rather than quality or other things while others were not concerned about it. The culture of consuming such products can benefit Apple in term of brand image of iPhone products, but this research can bring up different things.

Based on the background that has been described, the researcher is interested in conducting research entitled "The Effect of Country of Origin, Brand Image, Price Fairness and Service Quality Mediated by Consumer Satisfaction on Loyalty of iPhone Mobile Users in Yogyakarta"

\section{LiterATURE REVIEW}

\section{A. Country of Origin}

Country of origin is the impact that arises in consumer perceptions that are influenced by the location where the product is produced as in [12].

As in [34] basically, a country's image in a marketing perspective can be defined at three levels: 1 overall country image is the overall beliefs, ideas and impressions of a particular country as a result of consumer evaluations of their perceptions about the strengths and weaknesses of that country. 2. Aggregate product country image is the overall cognitive feeling associated with the product of a certain country. 3. Specific product country image is the overall cognitive feeling associated with the product specifications of a particular country

As in [11], country of origin indicators according to them are country innovation that produced product, technological advancements from that country, production design, production quality, and brand image of a brand producing country as a developed country.

As in [22], $\mathrm{COO}$ is related to the quality of the product itself. Consumers use the $\mathrm{COO}$ to be the standard quality of a product before the product / service is purchased by consumers. Thus, it creates brand image of these products.

Previous research as in [23] proved that Country of Origin has a positive effect on Brand Image. And also [24] in his research revealed that Country of Origin has a positive effect toward brand image. In this research, the hypothesis is proposed as follows:

H1: Country of origin has significant positive effect on brand image in using iPhone

\section{B. Brand Image}

As in [13], brand image is a set of beliefs, ideas or impressions that a person has toward a brand.

Companies must be able to develop brand images or product images so that it can continue to compete in competition in the business world. As in [32] there are 3 factors forming brand images, namely corporate image, product image, and user image.

As in [14], brand image indicators are strength of brand association, favorability of brand association, and uniqueness of brand association.

As in [25], Brand image is the link that is in the mind of consumers when remembering a particular brand. The image of a brand will be closely related to customer satisfaction.

As in [16], he stated that brand image has a positive and significant effect on customer satisfaction. In this research, the hypothesis is proposed as follows:

H2: Brand image has significant positive effect on customer satisfaction in using iPhone.

\section{Service Quality}

Service Quality is a person's assessment of the place or location, people, equipment, communication tools and prices they see before they decide to repurchase in the future as in [17].

The purpose and function of the service is the quality of service provided to consumers must function to better provide maximum satisfaction, therefore in order to provide services it must be carried out in accordance with the service function and the quality of service provided by each company has a purpose. Usually the purpose of holding a service is so that consumers feel the satisfaction and impact on the company will get the maximum profit. The quality of service expected and felt is determined by the quality of the service itself.

Service Quality Indicators as in [16] have leaflets or information, and provide information on product choices for iPhone. This can make purchases easily because they have ease of information, ease to exchange goods, and ease to find spare parts.

Previous research that examined the effect of service quality on customer satisfaction stated that service quality had a significant positive effect on customer satisfaction as in [26]. In this research, the hypothesis is proposed as follows:

H3: Service quality has significant positive effect on customer satisfaction in using iPhone

\section{Price Fairness}

Consumer's view of the differences in prices and benefits obtained by consumers can be considered or the price that is still acceptable as in [15], therefore, the selling price is likely to be compared with an experience of use before making a purchase.

As in [33] the consequence of this, when consumers feel that the benefits provided / offered by a product in connection with perceived high sacrifice, consumers will feel that the price is fair, it is referred to as price fairness. As in [16], price fairness indicators are affordable prices, stable prices, competitive prices, and low prices. Consumers who have full control to choose one of the various options offered previously will certainly compare whether the price offered is equal to the value or benefits to be received. 
As in [29], price fairness has positive and significant effect on customer satisfaction. In this research, the hypothesis is proposed as follows:

H4: Price fairness has significant positive effect on customer satisfaction in using iPhone.

\section{E. Customer Satisfaction}

As in [18], Consumer satisfaction is a consumer feeling, whether in the form of pleasure or disappointment arising from comparing the appearance of a product associated with consumer expectations for the product.

As in [27], he defined customer satisfaction as consumer feelings, whether in the form of pleasure or disappointment obtained from comparing the appearance of a product related to consumer expectations of the product.

Indicators of customer satisfaction as in [19] are satisfied with mobile design, satisfied with mobile features, handphone has clear voice, handphone has complete picture and features compared to other brands, satisfied with various bonuses such as adding applications and when the purchase is made, satisfied because the best brand, feel comfortable with the brand, the brand is more effective than other brands, and this brand can meet the needs.

As in [29], they stated that consumer satisfaction has a positive and significant influence on brand loyalty. In this research, the hypothesis is proposed as follows:

H5: Consumer satisfaction has significant positive effect on Brand Loyalty in using iPhone.

\section{F. Brand Loyalty}

Brand loyalty is the customer's consistent preference to make purchases on the same brand on specific products or certain service categories as in [20].

As in [35] aspects of brand loyalty consists of three types: 1. cognitive is a picture of what is believed by consumers. This component contains a consumer's perception, trust and stereotype of a brand, 2. Affective is a component based on consumers feelings about a product. Consumers have emotional closeness to the brand, 3. Conative is the boundary between the dimensions of attitude loyalty and behavior loyalty, which is represented through the tendency of consumer behavior to use the same brand in the future opportunity. This component is also related to the tendency of consumers to buy a brand because it has formed a commitment in themselves to continue to consume the same brand, 4. action is to recommend a certain product brand to others

As in [21], indicators of loyalty are desire to make purchases in the future, purchasing mobile phones as the main reference, recommending others who ask for advice, and willing to tell the benefits of the product.

\section{G. Structural Equation Model (SEM)}

A method used with the aim of processing research results in order to obtain a conclusion is called the data analysis method. As in [31] SEM is an amalgamation of separate statistical methods, namely factor analysis and simultaneous equation modeling.

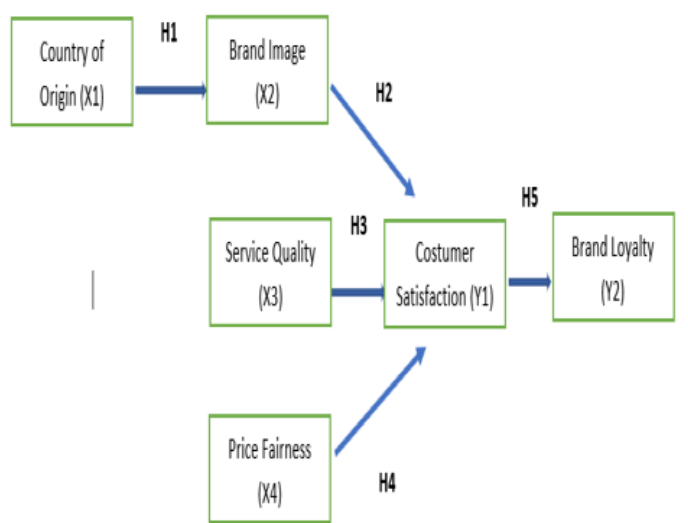

Fig. 1. Research Frame Work.

\section{RESEARCH AND DISCUSSION}

The research was quantitative primary. In this research, the populations were consumers of iPhone mobile users at the university in Yogyakarta who were currently using iPhone. The sample was taken using purposive sampling method with non-probability technique. The numbers of sample in this research were 250 respondents. The data was tested and processed using SEM AMOS 21.

\section{RESEARCH METHOD}

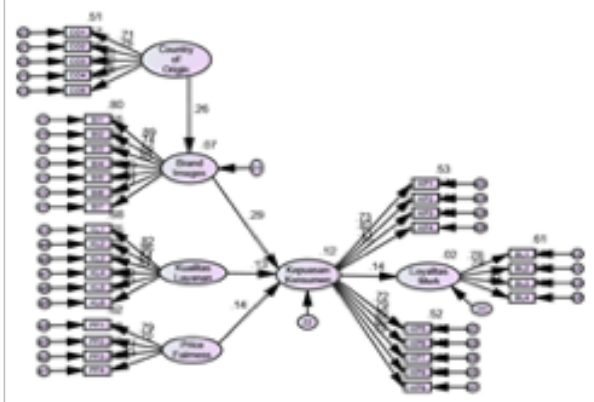

Fig. 2. Structural Equation Model.

\begin{tabular}{|l|c|c|c|}
\multicolumn{5}{|c|}{ TABLE 1: GOODNESS OF FIT TEST } \\
\hline \multicolumn{1}{|c|}{ index } & Cut-off Value & Result & Model Evaluation \\
\hline$\chi^{2}$ (Chi-Square) & Expected small & 996.058 & Deficient \\
\hline Probability & $\geq 0,05$ & 0.000 & Deficient \\
\hline CMIN & $\leq 2$ & 1.901 & Good fit \\
\hline GFI & $\geq 0,90$ & 0.800 & Moderate fit \\
\hline AGFI & $\geq 0,90$ & 0.800 & Moderate fit \\
\hline NFI & $\geq 0,90$ & 0.856 & Moderate fit \\
\hline TLI & $\geq 0,90$ & 0.915 & Good fit \\
\hline CFI & $\geq 0,90$ & 0.925 & Good fit \\
\hline IFI & $\geq 0,90$ & 0.926 & Good fit \\
\hline RMSEA & $\leq 0,08$ & 0.058 & Good fit \\
\hline
\end{tabular}

Source: Data Processed From 2019

Goodness of fit test results indicate that the assessment criteria are mostly categorized as good fit and moderate fit, therefore it can be concluded that overall the model is good and is stated goodness of fit. 


\section{A. Normality test}

Normality test is used to assess whether the data distribution is normally distributed or not. Data is said to be normally distributed if it has a multivariate critical ratio value of $-2.58<$ critical ratio $<2.58$.

Based on the result of data processed, it is known that the multivariate c.r value of $2,293<2.58$. Therefore it can be concluded that the data used in the study have been normally distributed.

\section{B. Outlier Test}

Outlier test is used to see if there is extreme data on a variable and makes the data very different from other data.

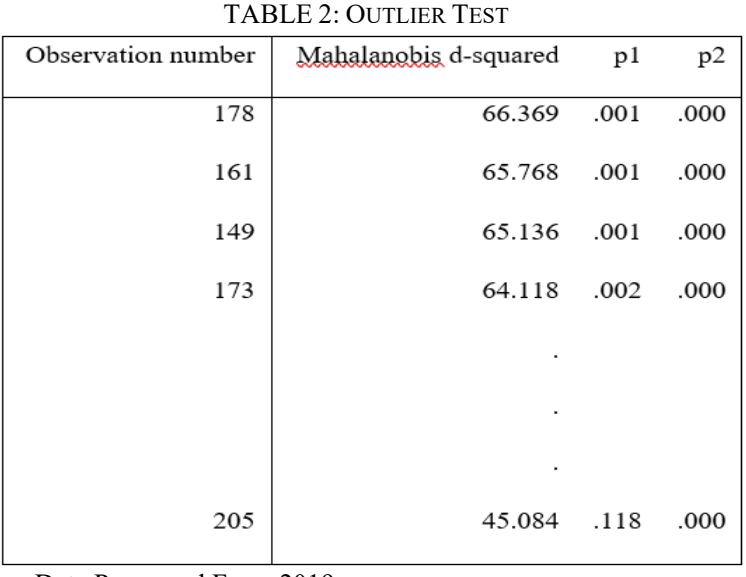

Source: Data Processed From 2019

Based on the outlier test results it is known that the highest d-square value is 66,369 and the lowest is 45,084 . While the mahalanobis distance in the table is 66,619 . Because the $\mathrm{d}$-square mahalanobis value is not higher 66,619 , it can be concluded that in this reseach there is no outlier data.

TABLE 3: HYPHOTHESIS TEST RESULT

\begin{tabular}{|l|r|l|r|r|r|r|}
\hline & & & Estimate & S.E. & C.R. & P \\
\hline Brand Image & $<---$ & Country of Origin & .285 & .074 & 3.856 & .000 \\
\hline Costumer Satisfaction & $<---$ & Brand Image & .282 & .064 & 4.385 & .000 \\
\hline Costumer Satisfaction & $<---$ & Service Quality & .124 & .063 & 1.974 & .048 \\
\hline Costumer Satisfaction & $<---$ & Price Fairness & .148 & .073 & 2.020 & .043 \\
\hline Brand Loyalty & $<---$ & Costumer Satisfaction & .148 & .072 & 2.051 & .040 \\
& & & & & & \\
\hline
\end{tabular}

Source: Data Processed From 2019

\section{Information:}

Source: Data Processed from 2019

Description:

If $\mathrm{p}$ value $<0.05$ the hypothesis is accepted.

If $\mathrm{p}$ value $>0.05$ the hypothesis is rejected.

\section{The Effect of COO on Brand Image}

Based on the analysis, it is known that country of origin had significant positive effect on brand image. That is, the better the country of origin of a product will further enhance the brand image of a product in the eyes of consumers.

The results of this research were in line with research as in [12] which stated that country of origin can be interpreted as a result that arises in the minds of consumers and influence the location where a product is created or produced. The location of a product created will affect people's perception of the quality of the product to be purchased.

\section{The Effect of Brand Image on Customer Satisfaction}

The analysis showed that brand image proved to have a significant positive effect on customer satisfaction. This means that the better the brand image of a product according to consumers, the better the level of satisfaction felt by consumers.

The results of this research were in line with research as in [16] that proved brand image has positive effect on consumer satisfaction.

\section{E. The Effect of Service Quality on Customer} Satisfaction

Based on the results of the research note, the quality of service was proven to have a positive influence on customer satisfaction. These results meant that the better the quality of services provided to consumer, the level of customer satisfaction will also increase. On the other hand, the lower the quality of services provided by consumers, the level of customer satisfaction will decrease.

The results of this research were in line with research as in [29] which stated that service quality has positive effect on service satisfaction. As in [26] revealed that service quality has positive effect on customer satisfaction.

\section{F. The Effect of Consumer Satisfaction on Brand Loyalty}

Based on the results of the analysis note, customer satisfaction had significant positive effect on brand loyalty. Increasing consumer satisfaction will also increase consumer loyalty to the brand.

The results of this research were in line as in [27] that proved Consumer Satisfaction has positive effect on brand loyalty.

\section{CONCLUSION AND RECOMMENDATION}

\section{A. Conclusion}

After the researcher conducted analysis and discussion, several conclusions are as follow: country of origin had positive and significant effect on brand image. This means that the better the consumer's assessment of the country of origin, the better the brand image as seen by consumers of iPhone. Brand image had positive and significant effect on customer satisfaction. This means that the better the brand image of iPhone, the better the iPhone customer satisfaction. Service quality had positive and significant effect on customer satisfaction. This means that the better the service quality provided to iPhone consumers, the better the level of iPhone customer satisfaction. Price fairness had positive and significant effect on customer satisfaction. This means that the better the price fairness of iPhone, the better the level of 
consumer satisfaction. Consumer satisfaction had positive and significant effect on brand loyalty. This means that the better the customer satisfaction, the better the level of brand loyalty.

\section{B. Recommendation}

Companies need to utilize and maximize the country of origin variable as a marketing aspect because of all the existing variables such as service quality, and price fairness all producers can maximize it and duplicate it, because the results of this study are able to prove that the country of origin variable has the biggest effect on brand images and brand images affect customer satisfaction and Companies should pay attention to customer satisfaction by continuing to maintain and improve brand image, service quality, and price fairness. Especially an increase in the dimensions of service quality that has the lowest value among other dimensions such as adding a store as a place of service and purchasing parts that will facilitate customers.

\section{ACKNOWLEDGMENT}

We would like to thank for any kind of supports from Post-Graduate Program, Department of Management, Faculty of Business and Economics, Universitas Islam Indonesia that possible this research published.

\section{REFERENCES}

[1] emarketer.com. (2013, 2 August). Smartphone penetration doubles in Indone-sia. Retrived on 5 oktober 2019, from https://www.emarketer. com/Article/Smartphone-Penetration-Doubles-Indonesia/1010102

[2] industry.co.id. (2018, 7 March). GFK: Indutri Smartphone Indonesia Meningkat Dalam Dua Tahun Terakhir. Retrieved on 6 Juni 2018 from https://www.industry.co.id/read/27584/gfk-industri-smartphoneindonesia-meningkat-dalam-dua-tahun-terakhir.

[3] gartner.com. (2018, 28 August). Gartner Says Huawei Secured No.2 Worldwide Smartphone Vendor Spot, Surpassing Apple in Second Quarter 2018. Retrived on 7 June 2019, from https://www. gartner. com/en/newsroom/press-releases/2018-08-28-gartner-says-huaweisecured-no-2-worldwide-smartphone-vendor-spot-surpassing-applein-second-quarter

[4] Naser, K., Jamal A. \& Khatib K. (1999). Islamic Banking: A Study of Customer Satisfaction and Perferences in Jordan. International Journal Of Banking Marketing, 17 (3), 135-150

[5] Fornell, J.D., Anderson, W.E., Eugene, Jaesung, C., \& Bryan, E.B. (1996). The American Customer Satisfaction Index: Nature, Purpose and Findings. Journal of Marketing, 60, 7-12

[6] Andreassen,T.W., \& Lindestad, B. (1998). Customer Loyalty and Complex Services. Internationl Journal of Service Industry Management, 9(1), 7-23

[7] Cronin, J.J \& Taylor, S.A. (1992). Measuring Service Quality: A Reexaminataion and Extension.Journal of Marketing. (56): 55-68.

[8] Tjiptono, F. (2008). Strategi Pemasaran. Edisi 3. ANDI: Yogyakarta

[9] Tjiptono, F. (2014). Customer Satisfaction. Andi: Yogyakarta

[10] Samiee, S. (1994), Customer Evaluation of Products In A Global Market, Journal of Inter national Business Studies. 25 (3), 579-604.

[11] Parameswaran, R., \& Pisharodi, R.M. (1994). Facets of Country of Origin Image an Empirical Assesment. Journal of Advertising. 23 (1), 43-56.

[12] Czinkota. M., \& Ronkainen, I. (2001). Global Marketing 2000: A Marketing Survival Guide. Marketing Management, 1(1): 36-45

[13] Simamora, B. (2004). Panduan Riset Perilaku Konsumen. Jakarta: PT.Gramedia Pustaka Utama.

[14] Keller, K.L. (1993). Conseptualizing, Measuring, and Managing Customer- Based on Brand Equity, Journal of Marketing, Vol. 57(1), $1-22$.

[15] Matzler, K., Brigit, R., \& Faullant, R. (2007). Dimensions of Price satisfaction : A Replication And Extention. The International Journal of Bank Marketing, 25 (6), 394-405.

[16] Ehsan, M.M. (2012). Impact of Brand Image, Service Quality and Price on Customer Satisfaction in Pakistan Telecommunication
Sector. International Journal of Business and Social Science. 3(23), 123-129

[17] Kotler, P. (2009). Manajemen Pemasaran. Edisi tiga belas Bahasa Indonesia. Jilid 1 dan 2. Jakarta: Erlangga

[18] Kotler, P., \& Keller, K. L. (2003). Manajemen Pemasaran. Edisi 13 Jilid 1 dan 2. Jakarta: Erlangga.

[19] Talat, M. (2012). The Relationships Between Brand Trust, Costumer Satisfaction and Costumer Loyalty (Evidence From Automobile Sector Of Pakistan). Interdisciplinary Journal of Contemporary Research In Business, 4(1)

[20] Schiffman, L \& Kanuk, L. L. (2008). Perilaku Konsumen Edisi 7. Jakarta: Indeks.

[21] Giddens. (2002). Customer Loyalty Menumbuhkan dan Mempertahankan Kesetiaan Pelanggan. Ahli Bahasa : Dwi Kartini Jaya. Revised and latest edition. Jakarta : Erlangga.

[22] Sanyal, S.N. \& Saroj, K.D. (2011). The Effect of Country Origin on Brand Equity: An Empirical Study on Generic Drugs. Journal of Product \& Brand Management. 20 (2), 130- 140

[23] Koubaa, Y. (2008). Country of origin, brand image perception, and brand image structure, Asia Pacific Journal of Marketing, Vol (2), 139-155.

[24] Tati, U.W., \& Yulianto, E. (2015). Pengaruh Country Of Origin Dan Global Brand Image Terhadap Minat Beli Dan Keputusan Pembelian (Survei pada Konsumen yang Membeli Smartphone Samsung Galaxy di Asia Tenggara. Jurnal Administrasi Bisnis, 25 (1), 1-10

[25] Shimp, T. (2003). Periklanan Promosi dan Aspek Tambahan Komunikasi Pemasaran Terpadu. Jakarta: Erlangga.

[26] Hadiati, S. (2003). Analisis Pengaruh Kualitas Pelayanan terhadap Kepuasan Nasabah Bank Widyana Malang. Jurnal KOMPAK, 8

[27] Nazaria, M., Hoseeni, M., Kaejahe S, (2014). Impact of price fairness on price satisfaction, costumer satisfaction and costumer loyalty in iran telecommunication market. asian journal of research marketing, 3(1), 131-144

[28] Keller, K.L. (2003). Strategic Brand Management, Building Measurement and Managing Brand Equity. Upper Sadle River, NJ Person Education Internasional

[29] Iskandar, A., \& Bernarto, I. (2007). Pengaruh Kualitas Pelayanan Restoran Platinum Lippo Karawaci terhadap Loyalitas Pelanggan: Kepuasan Pelanggan Sebagai Variabel Intervening. Jurnal Manajemen, 2(2), 143 - 163.

[30] Lai, K.K.Y dan Zaichkowsky, J.L. (1999). Brand Imitation: Do To Chinese Have Different Views?. Asia Pacific Journal of Management. 16 (2),179-92.

[31] Ghozali, I. (2011). Aplikasi Analisis Multivariat Dengan Program SPSS. Semarang: Badan Penerbit Universitas Diponegoro

[32] Aaker, D., \& Biel, A. (2013). Brand Equity and Advertising: Advertising's Role Building Strong Brands. Michigan: Psychology Press

[33] Dodds, B., \& Kent B.M. (1985). The Effect of Brand and Price Information on Subjective Product Evaluations, in Advances in Consumer Research, Vol. 12, Elizabeth C

[34] Lin, C.H., \& Kao, D.T. 2004, The Impacts of Country-of-Origin on Brand Equity. The Journal of American Academy of Business, Cambridge.

[35] Schiffman, L.G., \& Kanuk, L.L. (2010). Consumer Behaviour (10th ed). New Jersey, Pearson Prentice Hall.

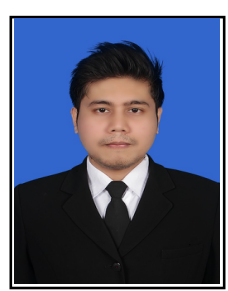

Frydom Nainggolan was born on October 31, 1993 in North Sumatra, Indonesia, He graduated from Diponegoro University in 2016 majoring in Industrial Engineering. He continued his post-graduated in Master of Management at Universitas Islam Indonesia, and graduated in 2020 .

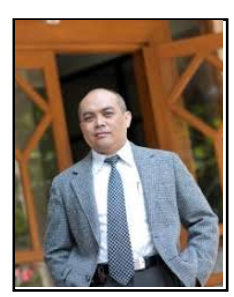

Anas Hidayat was born on July 27, 1962 in Yogyakarta, Indonesia. He Completed his Doctoral Program at Edith Cowan University, Western Australia in 2008. He is working for Management Department, Faculty of Business and Economics, Universitas Islam Indonesia as an Associate Professor. 